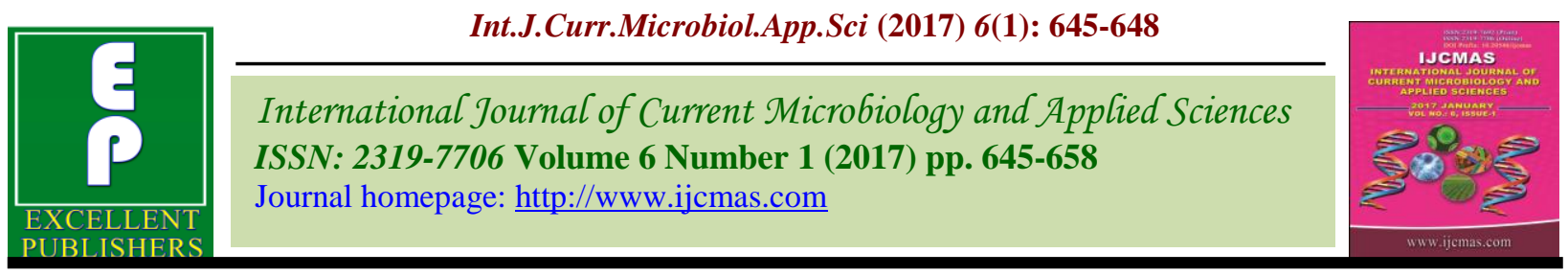

Original Research Article

http://dx.doi.org/10.20546/ijcmas.2017.601.078

\title{
Prevalence of TEM and SHV Genes among Extended Spectrum Beta- Lactamase (ESBL) Producing Escherichia coli Isolates from Infected Diabetic Foot Ulcers in a Tertiary Care Hospital
}

\author{
K. Akila*, S. Sivasankari, S. Senthamarai, C. Anitha, \\ M. Kumudavathi and K. Muthulakshmi
}
Meenakshi Medical College and Research Institute, Enathur, Kanchipuram, Tamilnadu, India
*Corresponding author

\section{A B S T R A C T}

\section{Keywords \\ Diabetic foot ulcer, Escherichia Coli, extended spectrum beta-lactamase (ESBL), TEM, SHV and CTX- $\mathrm{M}$ type genes.}

\section{Article Info}

Accepted:

29 December 2016

Available Online:

10 January 2017
The infection of diabetic foot ulcer is a debilitating complication of long standing diabetes especially with resistant bacteria. The production of extended spectrum beta-lactamase (ESBL) by gram negative bacteria is widely prevalent. This study was carried out to identify the prevalence, antimicrobial resistant pattern, ESBL production and the presence of TEM and SHV genes among ESBL producing Escherichia Coli. A total of 173 isolates were identified from 100 diabetic patients averaging 1.73 isolates per patient. Out of 173 isolates, $118(68 \%)$ were gram negative bacilli and $55(32 \%)$ were gram positive cocci and 38 were E.coli isolates $(21.96 \%)$. The ESBL confirmatory test has found $18(47.37 \%)$ (ESBL) producing strains of E.coli. The genotypic characterization of 18 ESBL producing E.Coli isolates by PCR has found that 12 (66.67\%) isolates had TEM, one $(5.56 \%)$ had SHV and one $(5.56 \%)$ had both TEM and SHV genes. The molecular microbiological techniques can rapidly identify pathogens, the resistant genes and virulence factors. The culture method often underestimates the microbial load, diversity and the prevalence of fastidious and anaerobic bacteria. Treatment by multidisciplinary team with appropriate antibiotics, surgical debridement and proper wound care helps to improve outcome in infected diabetic foot ulcer.

\section{Introduction}

In India, there were 69.1 million cases of diabetes in 2015 according to International Diabetes Federation. The increase in life expectancy and sedentary modern life style will certainly further increase the prevalence in the years to come (IDF Diabetes atlas, 2015) The foot ulcer and its subsequent aerobic, anaerobic bacterial and fungal infection is a debilitating complication of long standing diabetes, more so in poorly controlled diabetes (Lipsky et al., 2012; Chincholikar DA et al., 2002) The incidence of diabetic foot ulcer may be as high as $25 \%$ in diabetic patients during their lifetime (Singh et al., 2005). Prevention of foot ulcer is essential to reduce morbidity and mortality, but when foot ulcer develops due to altered mechanical load in a neuropathic foot, infection inevitably follows as an 'epiphenomenon' in about $40-80 \%$ of patients (Singh et al., 2005; Uckay et al., 2015; Lavigne et al., 2015).

The wound once established provides ideal niche for 'critical colonization' of taxonomically diverse bacterial pathogens 
either virulent or opportunistic and to cause subsequent repeated episodes of overt infection because of the micro-vascular and immune changes of long standing hyperglycemia (Lipsky et al., 2012). Diabetes is the leading cause of non traumatic lower extremity amputation as a consequence of foot ulcer and its related complications such as extensive skin and soft tissue infection (SSI) with or without osteomyelitis and wet gangrene. Infected diabetic foot ulcer is the leading cause of frequent and prolonged hospitalizations in diabetic patients (Singh et al., 2005).

Most often the infection is due to monobacterial etiology in the early stages. The factors such as antibiotic therapy, hospitalization and severity of ulcer cause longitudinal shift in microbial flora. In prolonged ulcer with higher Wagner's grade, the infection is usually caused by mixed aerobic and anaerobic bacteria (Ramakant et al., 2011). In temperate and western countries the aerobic gram positive cocci, Staphylococcus aureus is the predominant organism isolated often methicillin resistant in recent times. In warm subtropical countries like India, many studies reported mixed polymicrobial infection with the predominant organisms being aerobic gram negative bacilli such as Enterobactericeae, Pseudomonas aeruginosa (Uckay et al., 2015; Ramakant et al., 2011). Bacteroides fragilis, Peptostreptococcus spp., are some of the frequently implicated obligate anaerobic bacteria in the infection of diabetic foot ulcer (Halpati et al., 2014).

The culture based diagnostic techniques often underestimate the microbial load, diversity and the prevalence of fastidious and anaerobic bacteria and their role in the complex pathophysiology of diabetic foot ulcer infection. (Gardener et al., 2013; Lavigne et $a l ., 2015)$. The swab technique also affects the flora obtained. The bio-film formation on the surface of chronic wounds by infecting bacteria often contributes to chronicity of the wounds. The sessile forms encased in extracellular matrix are highly resistant to antibiotics than free living planktonic forms and difficult to clear by host immune system causing persistent infections (Zubair et al., 2011; Swarna et al., 2012).

The recent surveillance studies show many of these organisms often bear multiple resistant mechanisms. The production of extended spectrum beta lactamase (ESBL) by gram negative bacilli is one of them (Gadapelli et al., 2006; Shanmugam et al., 2013). The enzymes with hydrolytic ability against penicillins, second and third generation cephalosporins and monobctams but not against cephamycins with beta lactamse inhibitor susceptibility are called as "extended spectrum beta-lactamases" (ESBL). They are structurally serine beta lactamases belonging to Ambler class A, C and D. In functional Bush-Jacoby-Medeiros classification they are placed under 2be, 2d groups. (Bush et al., 1995) Since the first report of plasmid gene encoding beta-lactamase in 1983 in Germany capable of metabolizing extended spectrum oxyimino cephalosporins, the number of extended spectrum beta-lactamase (ESBL) genes expanded considerably and spread across all geographical regions of the world and across many species of bacteria (Livermore, 1995; Bradford, 2001; Paterson et al., 2005). A single isolate can harbor multiple ESBL genes and produce enzymes with different substrate specificities in different quantities simultaneously and exhibit antibiotic co-resistance i.e. resistance to multiple classes of antibiotics (Manoharan et al., 2011; Gadapelli et al., 2006); At present the number of distinct beta-lactamase gene alleles exceeds 1500 (Catalogued/ curated by G. Jacoby and K. Bush upto June 2015 (http://www.lahey.org/Studies/). Since 
July 2015 the data has been hosted by National Centre for Biotechnology Information, USA (NCBI) (https://www.ncbi.nlm.nih.gov/ pathogens/beta-lactamase-data-resources/)

There are many types of ESBLs but most are derived from TEM-1, TEM-2 and SHV-1 beta-lactamase types by mutation with less than $2 \%$ difference in amino acid sequences. The other types include CTX-M, few OXA variants (Paterson et al., 2005) In recent times the CTX-M type ESBL genes has emerged as the most common type found among gram negative bacilli worldwide (Bonnet, 2004; Canton et al., 2012).

This study was carried out to identify the prevalence of E.coli among various isolates from infected diabetic foot ulcer in a tertiary care hospital. The antimicrobial resistant pattern of the isolated E.coli strains and phenotypes which produce ESBL was also observed. The prevalence of TEM and SHV genes among extended spectrum betalactamase (ESBL) producing Escherichia coli was determined by polymerase chain reaction (PCR).

\section{Materials and Methods}

\section{Study design and Clinical examination}

This study was carried out in the Microbiology department of a tertiary care hospital for a period of twelve months between March 2013 to February 2014 after obtaining hospital ethical committee approval. After getting informed consent, 100 diabetic patients of all ages and both sexes were included in the study. The detailed history of the patient regarding age, sex, duration and type of diabetes, duration of ulcer has been obtained. The foot ulcers were graded according to Wagner's grade. One hundred samples either of pus or wound swabs were obtained from foot ulcer of Grade 1 or more after careful aseptic precautions from deeper portions of the ulcers.

\section{Microbiological methods}

Two swabs were collected from each patient, one swab was used for Gram staining and the other one used for culture and sensitivity. All samples were subjected to direct Gram staining and examined for pus cells. All samples were inoculated onto nutrient agar, 5\% sheep blood agar, Mac Conkey's agar and incubated at $37^{\circ} \mathrm{C}$ for 24 hours under aerobic conditions. The next day the specimens were examined for growth and colony morphology. The specimens were subjected to further processing depending upon the nature of the isolates as was determined by Gram staining and the colony morphology. The organisms were identified to species level as per standard protocols. The Escherichia coli ATCC25922 strain was included as the quality control strain (Koneman's Color atlas $\&$ diagnostic Microbiology, sixth edition, 2006).

\section{Antimicrobial susceptibility testing}

The antimicrobial susceptibility testing was done by Kirby Bauer disc diffusion method with commercially available discs (Hi Media Laboratories). The inoculums were adjusted to the turbidity of $0.5 \mathrm{McFarland}$ standard and swabbed onto the surface of Muller Hinton agar. The results were interpreted after measuring the zone of inhibition in millimeters $(\mathrm{mm})$ around the disc according to the Clinical \& Laboratory Standards Institute guidelines (CLSI M100-S22, 2012) The following antibiotic discs were used: Amoxycillin/Clavulanic acid 20/10 (30 mcg), Gentamicin $(10 \mathrm{mcg})$, Amikacin $(30 \mathrm{mcg})$, Ciprofloxacin $(5 \mathrm{mcg})$, Ceftazidime $(30 \mathrm{mcg})$, Cefuroxime $(30 \mathrm{mcg})$, Ceftriaxone $(30 \mathrm{mcg})$, Cefotaxime (30 mcg), Cefepime ( $30 \mathrm{mcg})$, Imipenem (10 mcg), Piperacillin/Tazobactam $(100 / 10 \mathrm{mcg})$ and Co-trimoxazole $(25 \mathrm{mcg})$. 
ESBL screening in Escherichia coli isolates

The screening for ESBL production was based on the size of specific zone of inhibition in millimeters to indicator cephalosporins, Ceftriaxone $(30 \mathrm{mcg})$, Cefotaxime $(30 \mathrm{mcg})$ and Ceftazidime $(30$ $\mathrm{mcg}$ ). Isolates exhibiting the zone size < $25 \mathrm{~mm}$ with Ceftriaxone, $<27 \mathrm{~mm}$ with Cefotaxime and $<22 \mathrm{~mm}$ with Ceftazidime were considered as ESBL producers (CLSI M100-S22, 2012)

Phenotypic confirmatory test for ESBL (Combined disc diffusion method)

The Escherichia coli isolates were inoculated as a lawn culture on cation adjusted Mueller Hinton agar plate using a sterile cotton swab. The antibiotic discs Ceftazidime (30mcg) and Ceftazidime-clavulanic acid $(30 / 10 \mathrm{mcg})$ were placed $20 \mathrm{~mm}$ apart and agar plates were incubated at $37^{\circ} \mathrm{C}$ for 24 hours. An increase in zone diameter of $>5 \mathrm{~mm}$ around combined Ceftazidime/Clavulanic acid in comparison to Ceftazidime alone confirmed the organism to be an ESBL producer as shown in Figure 3 (CLSI M100-S22, 2012)

\section{Genotypic characterization}

The Deoxyribonucleic acid (DNA) was extracted from all phenotypic ESBL confirmatory test positive Escherichia coli isolates. Polymerase chain reaction (PCR) amplification was done with specific gene primers for TEM and SHV types.The genomic DNA from E.coli strains was extracted by using bacterial gDNA isolation kit (XG2411-01, Xcelris) as described by ElFiky et al., 2007.

Detection of ESBL genes by PCR: (Lal P et al., 2007)

Detection of ESBL resistance genes (TEM and SHV) was done as described by Lal et al., 2007.

\section{PCR reaction mixture $(20 \mu \mathrm{I})$}

- Premiq -10 $\mu \mathrm{l}$ (Buffer $1 \mathrm{X}, \mathrm{MgCl}_{2} 1.5 \mathrm{mM}$, Taq DNA polymerase $0.5 \mathrm{U}$, dNTPs $0.2 \mathrm{mM}$ )

- Forward primer - $1 \mu 1$

- Reverse primer - $1 \mu \mathrm{l}$

- Template - $1 \mu \mathrm{l}$

- Milli Q water - $7 \mu 1$

PCR cycling temperature for SHV

- Denaturation at $-94^{0} \mathrm{C}$ for $2 \mathrm{~min}$

- Denaturation at $-94^{0} \mathrm{C}$ for $1 \mathrm{~min}$

- Annealing at $-52^{\circ} \mathrm{C}$ for $30 \mathrm{sec} \quad--30$

- Extension at $-72^{0} \mathrm{C}$ for $45 \mathrm{sec}$ cycles

- Final Extension at $-72^{0} \mathrm{C}$ for $5 \mathrm{~min}$

- Holding at $-4^{0} \mathrm{C}$ for $5 \mathrm{~min}$

\section{PCR cycling temperature for TEM}

- Denaturation at $-94^{\circ} \mathrm{C}$ for $2 \mathrm{~min}$

- Denaturation at $-94^{0} \mathrm{C}$ for $1 \mathrm{~min}$

- Annealing at $-58^{\circ} \mathrm{C}$ for $1 \mathrm{~min}$

- Extension at $-72^{0} \mathrm{C}$ for $1 \mathrm{~min}$ cycles

- Final Extension at $-72^{0} \mathrm{C}$ for $7 \mathrm{~min}$

- Holding at $-4^{0} \mathrm{C}$ for $5 \mathrm{~min}$

Analysis of PCR products (amplicons)

After amplification, the amplicons were visualized on $1.5 \%$ agarose gel for the presence of band. The agarose gel were scanned under UV illumination, visualized and digitized with the gel documentation system (Mediscans) as shown in Figure 4.

\section{Results and Discussion}

A total of 173 isolates were identified from 100 diabetic patients with infected foot ulcers 
averaging 1.73 bacterial isolates per patient. Out of 100, 59 patients were in the age group of 41 to 60 years and 36 patients were in the age group of 61 to 80 years. The number of male patients included in the study was 67 compared to 33 females with gender ratio of 2:1 as depicted in Table 2. Only one had insulin dependent diabetes in the study with the rest being non insulin dependent diabetes mellitus. The duration of diabetes varied among patients. Out of 100 patients, $31 \%$ had diabetes for less than 5 years duration, 33\% had it for between 5 to 10 years and $36 \%$ had diabetes for more than 10 years (Table 3) At the time of inclusion in the study, $53 \%$ of patients in the study had foot ulcer of less than 1 month duration and $47 \%$ had it for more than a month (Table 4) The diabetic foot ulcers were assessed according to Wagner's grading. Most of the patients belonged to Grade 3 ulcer (39\%) followed by Grade 2 in $35 \%$. The Grade 4 ulcers were found in about $19 \%$ of patients. Only one had grade 5 ulcer (1\%) (Table 5)

Out of 100 samples, 93 had microbial growth of which 52 were polymicrobial and 41 samples had monomicrobial growth (Table 6) Out of 173 organisms isolated, 118 (68\%) were gram negative bacilli and $55(32 \%)$ were gram positive cocci (Table 7) Out of 173 organisms, there were 38 E.coli isolates and was the predominant organism isolates (21.96\%). This was followed by other gram negative bacilli such as Klebsiella spp 31 (17.92\%) and Pseudomonas aeruginosa 28 (16.18\%). The next being 27 (15.96\%) isolates of Staphylococcus aureus and was the most common among gram positive cocci. The coagulase negative Staphylococcus 12(6.94\%), Enterococcus spp. 10 (5.78\%) and Streptococcus pyogenes $6(3.47 \%)$ were the other gram positive cocci isolated from the ulcer specimens (Figure 2)

In the antimicrobial susceptibility testing of E.coli isolates by disc diffusion method, the high degree of resistance was observed with amoxicillin-clavulanic acid (81.50\%) followed by sulphonamide resistance which was about $78.00 \%$. The proportion of E.coli isolates showing resistance to third generation cephalosporins such as ceftazidime, ceftriaxone were $65.79 \%, 60.53 \%$ respectively. The percentage of ciprofloxacin and gentamicin resistant E.coli was $60.53 \%$, $52.63 \%$ respectively. All the 38 isolates were sensitive to piperazicillin-Tazobactam and imipenem (Table 8)

The phenotypic ESBL confirmatory test by combined disc diffusion method has found 18 $(47.37 \%)$ extended spectrum beta-lactamase (ESBL) producing strains among 38 isolates of E.coli (Table 9) The genotypic characterization of 18 ESBL producing E.coli isolates by PCR with the primers of TEM and SHV type beta lactamase variants has found that $12(66.67 \%)$ isolates had TEM type, one $(5.56 \%)$ had SHV and one $(5.56 \%)$ had both TEM and SHV genes. Four ESBL producing E.coli isolates had no TEM and or SHV genes (Table 10)

Infected diabetic foot ulcer is one of the debilitating complications of long standing poorly controlled diabetes. The risk of acquiring multi-drug resistance organisms is high due to chronic nature of ulcers, frequent hospitalizations and use of multiple antibiotics in the course of illness. This study showed the male preponderance in the occurrence of foot ulcer in diabetics. Relatively more outdoor activities in male gender with barefoot walking in India, smoking, tobacco use were cited as some of the reasons for this variation (Chincholikar et al., 2002; Tiwari et al., 2012). In this study $36 \%$ of patients with foot ulcers had diabetes for more than 10 years. A prospective cohort study involving 2840 patients found that the risk of lower limb amputation is 1.88 times higher in diabetics of more than 23 years (Gershater et al., 2009). 
Polymicrobial nature of diabetic foot infections has been observed in various studies in the subcontinent and abroad. In this study $52 \%$ of specimens had witnessed the growth of mixed flora and is in agreement with other studies (Anandi et al., 2004; Shankar et al., 2005; Ramakant et al., 2011; Citron et al., 2007; Dowd et al., 2008). Deep ulcers with large surface area and those of longer duration bear a diverse flora with predominance of aerobic gram negative bacilli and anaerobes (Gardener et al., 2013). In developing country like India the ulcers were often seen in advanced stage at presentation due to lack of awareness among diabetic patients from poor socioeconomic status.

Many studies in India had reported aerobic gram negative bacillary organisms to be more predominant in diabetic foot ulcer infection than aerobic gram positive cocci (Shankar et al., 2005; Bansal et al., 2008; Shanmugam et al., 2013; Gadepalli et al., 2006; Swarna et $a l ., 2012)$. Out of 173 organisms isolated 118 $(68 \%)$ were gram negative bacilli and 55 (32\%) were gram positive cocci in this study. A study by Tiwari et al., (2012) reported exactly similar figure of $68 \%$ gram negative bacilli and $32 \%$ gram positive cocci from 82 strains isolated from 62 patients with infected diabetic foot ulcer. Some of the possible reasons cited for this discrepancy include hot climate causing foot sweating, unfitting footwear, frequent foot washing and the suboptimal perineal/hand hygiene (Uckay et al., 2015; Ramakant et al., 2011) The Escherichia coli, 38 out of 173 total isolates $(21.96 \%)$ was the predominant organism identified followed by Klebsiella spp (31 out of $173,17.92 \%$ ) in this study. The study by Esmat et al., (2012) had reported similar results. Out of 163 total isolates, 35 (20.3\%) were E.coli and 29 (17.4\%) were Klebsiella pneumoniae. The study by Zubair et al., (2011) had reported that the Escherichia coli (41 out of 97 gram negative bacilli, 42.2\%) was the most common organism isolated. But the study by Ramakant et al., (2011) had found Pseudomonas aeruginosa as the predominant isolate, which was the third most common among gram negative bacilli in this study. Staphylococcus aureus (27 out of 173, $15.61 \%$ ) was the most common among gram positive cocci isolates.

In the antimicrobial susceptibility testing of E.coli isolates by disc diffusion method, the degree of resistance observed to third generation cephalosporins such as ceftazidime, ceftriaxone were $65.79 \%$, $60.53 \%$ respectively. The study by Gadepalli et al., (2006) had reported the proportion of E.coli isolates resistant to ceftazidime as $54.60 \%$. The percentage of ciprofloxacin and gentamicin resistant E.coli were $60.53 \%$, $52.63 \%$ respectively. All the 38 (100\%) isolates were sensitive to imipenem and is in concordant with these following studies, Varaiya et al., (2008), Bansal et al., (2008) and Shanmugam et al., (2013).

The emergence of ESBL enzymes is an evolutionary survival response against huge selection pressure exerted by very high betalactam antibiotic consumption worldwide. In 2010, India was the largest consumer of antibiotics (Laximinarayan et al., 2016; Van Boeckel et al., 2014). The spread of ESBL enzymes among the taxonomically diverse species of bacteria through plasmids with relative ease has led to dramatic increase in their prevalence. Prevalence of ESBLs varies widely in the different regions of India. The studies done by Anjali et al., (2013), Gadepalli et al., (2006) and Varaiya et al., (2008) had reported the proportion of E.coli isolates producing ESBLs as 50\%, 54.5\% and $48.38 \%$ respectively. In the present study, $47.37 \%$ (18 out of 38) E.coli isolates were found to be ESBL producers. All ESBL producing E.coli strains were sensitive to amikacin, piperacillin-tazobactam and 
imipenem in this study, which is similar to observations of Anjali et al., 2013. A pair of forward and reverse was used to amplify TEM and SHV genes by PCR followed by pulsed field gel electrophoresis in the molecular analysis. Among 18 ESBL producing E.coli isolates found in the present study, $12(66.67 \%)$ were harboring TEM gene and SHV gene was found in $1(5.56 \%)$. TEM and SHV genes were found in combination in 1 E.coli isolate $(5.56 \%)$. In the present study the molecular characterization of other ESBL gens such as CTX-M, OXA was not carried out.

Table.1 Primer sequences

\begin{tabular}{llc}
\hline Primer & Primer sequence (5'-3) & Product size (bp) \\
\hline SHV Forward & TCAGCGAAAAACACCTTG & 471 \\
SHV Reverse & TCCCGCAGATAAATCACC & 471 \\
TEM Forward & CTTCCTGTTTTGGCTCACCCA & 717 \\
TEM Reverse & TACGATACGGGAGGGCTTAC & 717 \\
\hline
\end{tabular}

Table.2 Patient's Age and Gender distribution

\begin{tabular}{cccc}
\hline Age (years) & Male N (\%) & Female $\mathrm{N}(\boldsymbol{\%})$ & Total N (\%) \\
\hline $21-40$ & $3(4.48 \%)$ & $1(3.03 \%)$ & $4(4 \%)$ \\
$41-60$ & $35(52.24 \%)$ & $24(72.73 \%)$ & $59(59 \%)$ \\
$61-80$ & $28(41.79 \%)$ & $8(24.24 \%)$ & $36(36 \%)$ \\
$>80$ & $1(1.49 \%)$ & $0(0 \%)$ & $1(1 \%)$ \\
Total & $67(100 \%)$ & $33(100 \%)$ & $100(100 \%)$ \\
\hline
\end{tabular}

Table.3 Distribution of duration of diabetes mellitus

\begin{tabular}{ccc}
\hline $\begin{array}{c}\text { Duration of } \\
\text { diabetes } \\
\text { (Years) }\end{array}$ & No. of cases & $\begin{array}{c}\text { Percentage } \\
(\boldsymbol{\%})\end{array}$ \\
\hline$<5$ & 31 & 31 \\
$5-10$ & 33 & 33 \\
$>10$ & 36 & 36 \\
Total & 100 & 100 \\
\hline
\end{tabular}

Table.4 Distribution of duration of ulcer

\begin{tabular}{ccc}
\hline Duration & $\begin{array}{c}\text { Number of } \\
\text { patients }\end{array}$ & $\begin{array}{c}\text { Percentage } \\
(\boldsymbol{\%})\end{array}$ \\
\hline$<1$ month & 53 & 53 \\
$>1$ month & 47 & 47 \\
Total & 100 & 100 \\
\hline
\end{tabular}


Table.5 Classification of ulcer by Meggit Wagner's grading system

\begin{tabular}{ccc}
\hline Grade & $\begin{array}{c}\text { Number of } \\
\text { patients }\end{array}$ & $\begin{array}{c}\text { Percentage } \\
(\boldsymbol{\%})\end{array}$ \\
\hline 1 & 6 & 6 \\
2 & 35 & 35 \\
3 & 39 & 39 \\
4 & 19 & 19 \\
5 & 1 & 1 \\
Total & 100 & 100 \\
\hline
\end{tabular}

Table.6 Distribution of Growth

\begin{tabular}{ccc}
\hline Growth & Number & $\begin{array}{c}\text { Percentage } \\
(\mathbf{\%})\end{array}$ \\
\hline Poly microbial & 52 & 52 \\
Mono & 41 & 41 \\
microbial & & \\
No growth & 7 & 7 \\
Total & 100 & 100 \\
\hline
\end{tabular}

Table.7 Distribution of micro organisms

\begin{tabular}{ccc}
\hline Organisms & Number & Percentage $(\%)$ \\
\hline Gram negative bacilli & 118 & 68 \\
Gram positive cocci & 55 & 32 \\
Total & 173 & 100 \\
\hline
\end{tabular}

Fig.1 Diabetic foot ulcer on the plantar surface of the foot

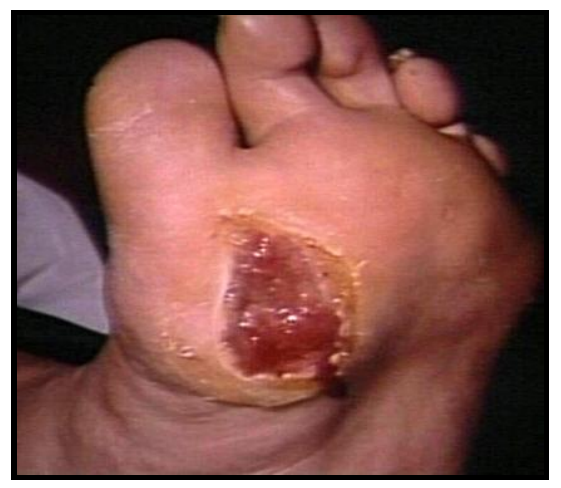


Table.8 Antimicrobial resistance pattern of Escherichia coli isolates (Done by Kirby Bauer disc diffusion method)

\begin{tabular}{|c|c|c|}
\hline Antimicrobial discs $(\mu \mathrm{g})$ & $\begin{array}{c}\text { Resistance } \\
\text { (Number) }\end{array}$ & $\begin{array}{c}\text { Resistance } \\
\text { (Percentage) }\end{array}$ \\
\hline $\begin{array}{l}\text { Cephalosporins: } \\
\text { Ceftazidime(30) }\end{array}$ & 25 & $65.79 \%$ \\
\hline Cefuroxime(30) & 24 & $63.15 \%$ \\
\hline Ceftriaxone (30) & 23 & $60.53 \%$ \\
\hline Cefepime(30) & 6 & $15.79 \%$ \\
\hline $\begin{array}{l}\text { Carbapenems: } \\
\text { Imipenem(10) }\end{array}$ & 0 & $0 \%$ \\
\hline $\begin{array}{l}\text { Aminoglycosides: } \\
\text { Gentamicin }(10)\end{array}$ & 20 & $52.63 \%$ \\
\hline $\operatorname{Amikacin}(30)$ & 2 & $5.20 \%$ \\
\hline $\begin{array}{l}\text { Quinolones: } \\
\text { Ciprofloxacin(5) }\end{array}$ & 23 & $60.53 \%$ \\
\hline $\begin{array}{l}\text { Sulphonamides: } \\
\text { Co-trimoxazole }(25)\end{array}$ & 30 & $78.00 \%$ \\
\hline $\begin{array}{l}\text { Penicillin/ } \\
\text { Beta-lactamase } \\
\text { inhibitor combination: } \\
\text { Amoxyclav }(20 / 10)\end{array}$ & 31 & $81.50 \%$ \\
\hline $\begin{array}{l}\text { Piperacillin- } \\
\text { tazobactam(100/10) }\end{array}$ & 0 & $0 \%$ \\
\hline
\end{tabular}

Table.9 Proportion of ESBL producing E.coli

\begin{tabular}{ccc}
\hline $\begin{array}{c}\text { Number of } \\
\text { E.coli } \text { isolates }\end{array}$ & ESBL isolates & $\begin{array}{c}\text { Percentage } \\
(\boldsymbol{\%})\end{array}$ \\
\hline 38 & 18 & 47.37 \\
\hline
\end{tabular}

Table.10 Distribution of ESBL genes among E.coli isolates

\begin{tabular}{ll}
\hline ESBL genes & Positive n $(\boldsymbol{\%})$ \\
\hline TEM & $12(66.67)$ \\
SHV & $1(5.56)$ \\
TEM+SHV & $1(5.56)$ \\
\hline
\end{tabular}


Fig.2 Prevalence of organisms isolated from ulcer

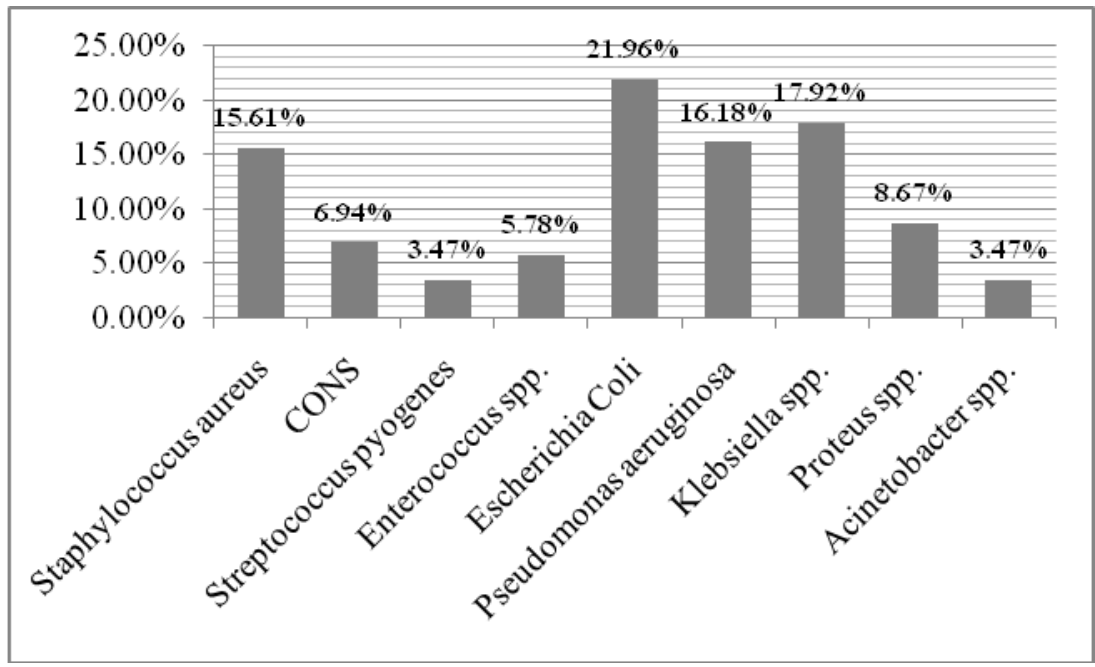

Fig.3 Showing phenotypic confirmation test for ESBL detection (Ceftazidime/clavulanic acid disc $(30 / 10 \mu \mathrm{g})$ showing increase in zone of inhibition by $>5 \mathrm{~mm}$ than ceftazidime disc $(30 \mu \mathrm{g})$ alone

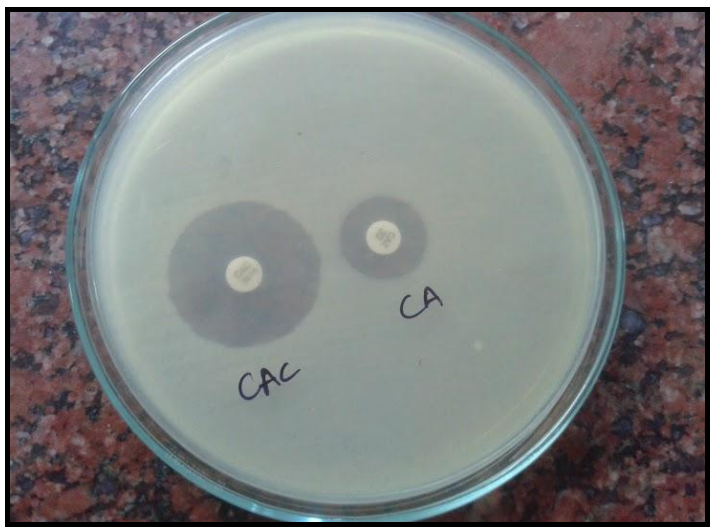

Fig.4 Agarose Gel picture shows lane M containing marker 100bp DNA ladder. Lane 1,2,4,7 shows positive amplicons for gene TEM (717bp) and lane 3 shows positive amplicon for gene SHV (471bp)

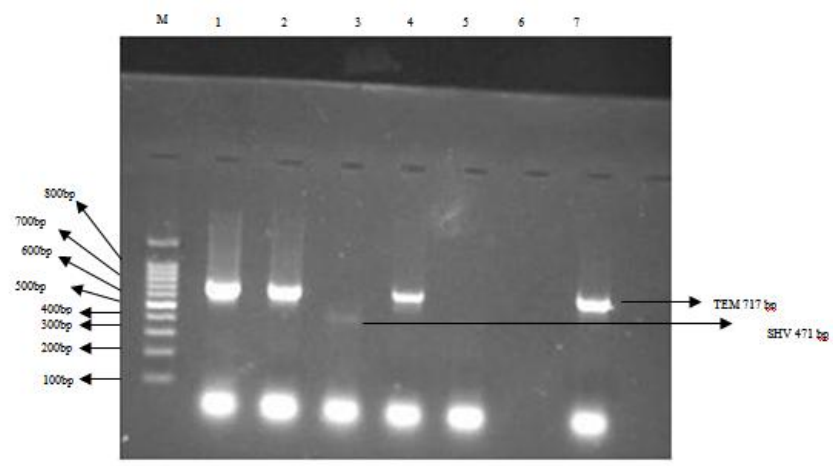


In a study by Sharma et al., (2010) out of 25 ESBL positive E.coli isolates, 13 harbored TEM genes, 12 harbored SHV gene. According to another study TEM type ESBL was the commonest and found in 32 out of 44 of E.coli strains which correlate with our study (Bali et al., 2010). Manoharan et al., SARI study group, a multicentre study carried out molecular characterization of ESBL genes among gram negative bacilli. CTX-M type is the most common (14 out of 46) followed by TEM (2 out of 46) when they had single gene. When in combination, strains which had both CTX-M and TEM were the common (22 out of 46) followed by strains which had (4 out of 46) all three types tested i.e. CTX-M, TEM and SHV (Manoharan et al., 2011).

A study by Vasumathi et al., (2016) had reported that out of 16 ESBL producing E.coli isolates $11(68.7 \%)$ had CTX-M followed by TEM in $2(12.5 \%)$ isolates. A study by Goyal et al., (2008) reported that out of 61 E.coli isolates subjected to PCR, 26 possessed single ESBL gene alone and 35 had two or more ESBL genes in combination. CTX-M type is the most common (23 out of 61) followed by TEM (3 out of 61) when they had single gene. When in combination, strains which had both CTX-M and TEM were the common (17 out of 61) followed by strains ( 9 out of 61) which had all three types tested i.e CTX-M, TEM and SHV (Goyal et al., 2008).

In conclusion, the identification of all the organisms infecting the wound and the in vitro-susceptibility testing should be rapid and accurate for targeted antibiotic therapy. The culture based diagnostic techniques often underestimate the microbial load, diversity and the prevalence of fastidious and anaerobic bacteria. The molecular microbiological techniques once become widely available and affordable offer a promising tool in rapidly identifying pathogens causing infection, the resistant genes they possess and to determine the virulence factors in them (Lavigne et al.,
2015; Lipsky et al., 2013; Spichler et al., 2015).

Early recognition of infection and prompt treatment with multidisciplinary team with appropriate antibiotics, pressure off loading and surgical debridement of necrotic tissue with proper wound care helps to improve the outcome in diabetic patients with infected foot ulcer (Lipsky et al., 2012).

\section{References}

Anandi, C., Alaguraja, D., natarajan, V., ramanathan, M., Subramaniam, C.S., Thuliram, m., Sumithra, S. 2004. Bacteriology of diabetic foot lesions. Indian J. Med. Microbiol., 22: 175-8.

Anjali, S., Jog, Shadija, P.G., Ghosh, S.J. 2013. Detection of multi drug resistant gram negative bacilli in type II diabetic foot infections. Int. J. Med. Heath Sci., 2: 186-194.

Bali, E.B., Accedil, L., Sultan, N. 2010. Phenotypic and molecular characterization of SHV, TEM, CTX-M and extended-spectrum-lactamase produced by Escherichia coli, Acinobacter baumannii and Klebsiella isolates in a Turkish hospital. African J. Microbiol. Res., 4(8): 650-4.

Bansal, E., Garg, A., Bhatia, S., Attri, A.K., Chander, J. 2008. Spectrum of microbial flora in diabetic ulcers. Indian J. Pathol. Microbiol., 51: 204-8.

Bonnet, R. 2004. Growing Group of Extended-Spectrum $\beta$-Lactamases: the CTX-M Enzymes. Antimicrobial Agents and Chemotherapy, 48(1):1-14.

Bradford, P.A. 2001. Extended spectrum betalactamases of $21^{\text {st }}$ century: Characterization, epidemiology and detection of this important resistant threat. Clin. Microbiol. Rev., 14: 933951.

Bush, K., Jacoby, G., Medeiros, A.A. 1995. A 
functional classification scheme for $\beta$ lactamases and its correlation with molecular structure. Antimicrob. Agents Chemother., 39:1211-1233.

Canton, R., Gonzalez-Alba, J.M., Galan, J.C. 2012. CTX-M Enzymes: Origin and Diffusion. Frontiers in Microbiol., 3:110.

Chincolikar, D.A., Pal, R.B. 2002. Study of fungal and bacteriological infections of the diabetic foot. Indian J. Pathol. Microbiol, 45: 15-22.

Citron, D.M., Goldstein, E.J., Merriam, C.V., Lipsky, B.A., Abramson, M.A. 2007. Bacteriology of moderate-to-severe diabetic foot infections and in vitro activity of antimicrobial agents. J. Clin. Microbiol., 45:2819-2828.

CLSI. 2012. Performance Standards for Antimicrobial Susceptibility Testing; Twenty second Informational Supplement. CLSI document M100S22. Clinical and Laboratory Standards Institute; Wayne, PA

Dowd, S.E., Wolcott, R.D., Sun, Y., McKeehan, T., Smith, E., Rhoads D., 2008. Polymicrobial nature of chronic diabetic foot ulcer biofilm infections determined using bacterial tag encoded FLX amplicon pyrosequencing (bTEFAP). PLoS One; 3:e3326.

El-Fiky, S., Elgandour, A., Harfoush, R., 2007. Phenotypic and Molecular Detection of TEM and SHV betalactamases produced by organisms of the family Enterobactericeae; Study on blood culture clinical isolates from intensive care unit. Egyptian J. Med. Microbiol., 16(2): 211-221.

Esmat, M.M., Al Islam, A.S. 2012. Diabetic foot infection: Bacteriological causes and antimicrobial therapy. The $J$. American Sci., 8(10): 389-393.

Gadepalli, R., Dhawan, B., Sreenivas, V., Kapil, A., Ammini, A.C. 2006. A clinicomicrobiological study of diabetic foot ulcers in an Indian tertiary care hospital Diabetes Care, 29(8):1727-32.

Gardner, S.E., Hillis, S.L., Heilmann K, Segre J.A., Grice, EA. 2013. The neuropathic diabetic foot ulcer microbiome is associated with clinical factors. Diabetes; 62:923-930.

Gershater, M.A., Londahl, M., Nyberg P, Larsson J, Thorne J, Eneroth M, Apelqvist J. 2009. Complexity of factors related to outcome of neuropathic and neuroischaemic/ ischaemic diabetic foot ulcers: a cohort study. Diabetologia, 52(3): 398-407.

Goyal, A., Prasad, KN, Prasad A, Gupta S, Ghoshal, U., Ayyagari, A. 2009. Extended spectrum beta-lactamases in Escherichia coli \& Klebsiella pneumoniae \& associated risk factors. Indian J Med Res; 129(6):695-700.

Halpati, A., Desai, K.J, Jadeja R, Parmar M. 2014. A study of aerobic and anaerobic bacteria in diabetic foot ulcer and in vitro sensitivity of antimicrobial agent. Int. J. Med. Sci. Public Health, 3(7): 818-821.

International Diabetes Federation, IDF Diabetes Atlas, 7th Edn, 2015. Brussels, Belgium: International Diabetes Federation. http://diabetesatlas.org

Jacoby, G. and Bush, K.,l http://www.lahey.org/Studies/ (last accessed 16-Dec-2016)

Koneman, E.W., Allen, S.D., Janda WM, Schreckenberger, P.C., Win WC, editors., 2006. The enterobacteriaceae. In: Color atlas and textbook of diagnostic microbiology Sixth edition (5) (Philadelphia, JB Lippincott Co, 2006) p. 211-302.

Lal, P., Kapil, A., Das, B.K., Sood, S. 2007. Occurrence of TEM and SHV gene in extended spectrum beta-lactamases (ESBLs) producing Klebsiella sp. isolated from a tertiary care hospital. Indian J. Med. Res., 125:173-8. 
Lavigne, J.P., Sotto, A., Dunyach-Remy, C., Lipsky, B.A. 2015. New Molecular Techniques to Study the Skin Microbiota of Diabetic Foot Ulcers. Adv. Wound Care, 4(1): 38-49.

Laxminarayan, R., Chaudhury, R.R. 2016. Antibiotic Resistance in India: Drivers and Opportunities for Action. PLoS Med., 13(3): e1001974.

Lipsky, B.A., Berendt, A.R., Cornia, P.B. et $a l ., 2012$. Infectious Diseases Society of America. Infectious Diseases Society of America clinical practice guideline for the diagnosis and treatment of diabetic foot infections. Clin. Infect. Dis., 54: e132-e173.

Lipsky, B.A., Richard, J.L., Lavigne, J.P. 2013. Diabetic foot ulcer microbiome: One small step for molecular biology...One giant leap for understanding diabetic foot ulcers? Diabetes; 62: 679-681.

Livermore, D.M. 1995. Beta-lactamases in laboratory and clinical resistance. Clin. Microbiol. Rev., 8: 557-584.

Manoharan, A., Premalatha, K., Chatterjee, S., Mathai, D, Group SS., 2011. Correlation of TEM, SHV and CTX-M extended-spectrum beta lactamases among Enterobacteriaceae with their in vitro antimicrobial susceptibility. Indian J. Med. Microbiol., 29(2): 161.

National Centre for Biotechnology Information, USA (NCBI) https://www.ncbi.nlm.nih.gov/pathogen s/beta-lactamase-data-resources/)

Paterson, D.L., Bonomo, R.A. 2005. Extended spectrum beta-lactamases: a clinical update. Clin. Microbiol. Rev., 18: 657-686.

Ramakant, P., Verma, A.K., Misra, R., Prasad K.N. 2011. Changing Microbiological profile of pathogenic bacteria in diabetic foot infections: time to rethink on which empirical therapy to chose? Diabetologica , 54(1): 58-64.
Shanker, E.M., Mohan, V., Premalatha, G, Srinivasan RS, Usha AR .2005. Bacterial etiology of diabetic foot infections in South India. Eur. J. Intern. Med., 16: 567-570.

Shanmugam, P., Jeya, M., Susan, S.L. 2013. The bacteriology of diabetic foot ulcers, with special reference to multi drug resistant strains. J. Clin. Diagn. Res., 7: 441-445.

Sharma, J., Sharma, M., Ray, P. 2010. Detection of TEM \&SHV genes in Escherichia coli \& Klebsiella pneumoniae isolates in a tertiary care hospital from India. Indian J. Med. Res., 132: 332-36.

Singh, N., Armstrong, D.G., Lipsky, B.A. Preventing foot ulcers in patients with diabetes. JAMA, 293(2): 217-28.

Swarna, S.R., Radha, M., Gomathi S, Devaraj and Thamaraiselvi. 2012. A study of biofilm on diabetic foot ulcer. Int. J. Res. pharmaceutical and Biomed. Sci., 3(4): 1809-1814.

Spichler, A., Hurwitz, B.L., Armstrong, D.G., Lipsky, B.A. 2015. Microbiology of diabetic foot infections: from Louis Pasteur to 'crime scene investigation'. BMC Med., 13(1):1.

Tiwari, S., Pratyush, D.D., Dwivedi, A., Gupta, S.K., Rai, M, Singh SK. 2012. Microbiological and clinical characteristics of diabetic foot infections in northern India. J. Infect. Dev. Ctries, 6(4): 329-332.

Uckay, I., Aragon-Sanchez, J., Lew, D., and Lipsky, B.A. 2015. Diabetic foot infections: what have we learned in the last 30 years? Int. J. Infect. Dis. 40, 8191.

Van Boeckel, T.P., Gandra, S., Ashok, A, Caudron, Q., Grenfell, B.T., Levin, S.A. and Laxminarayanan, R. 2014. Global antibiotic consumption 2000 to 2010: An Analysis of National pharmaceutical Sales Data. The Lancet Infec. Dis., 14: 
742-750.

Varaiya, A.Y., Dogra, J.D., Kulkarni, M.H., Bhalekar, P.N. 2008. Extendedspectrum beta-lactamaseproducing Escherichia coli and Klebsiella pneumoniae in diabetic foot infections. Indian $J$. Pathol. Microbiol., 51(3): 370-372.

Vasumathi, A., Thenmozhivalli, P.R., Senthamarai, S., Ramani, C.P.,
Jagadesan, R. 2016. Molecular characterization of TEM, SHV and CTX-M genes among ESBL producing gram negative isolates in ICU. Int. J. Curr. Res. Aca Rev., 4(2): 170 -175.

Zubair, M., Malik, A., Ahmad, J. 2010. Clinico-bacteriology and risk factors for the diabetic foot infection with multidrug resistant microorganisms in North India Biol. Med., 2(4): 22-34.

\section{How to cite this article:}

Akila, K., S. Sivasankari, S. Senthamarai, C. Anitha, M. Kumudavathi and Muthulakshmi, K. 2017. Prevalence of TEM and SHV Genes among Extended Spectrum Beta-Lactamase (ESBL) Producing Escherichia coli Isolates from Infected Diabetic Foot Ulcers in a Tertiary Care Hospital. Int.J.Curr.Microbiol.App.Sci. 6(1): 645-658.

doi: http://dx.doi.org/10.20546/ijcmas.2017.601.078 